\title{
SOIL AND LEAF WATER POTENTIAL OF QUERCUS SEMECARPIFOLIA AT PHULCHOWKI HILL, NEPAL
}

\author{
K. Poudyal \\ Amrit Science Campus, Lainchour, Kathmandu \\ Email: kantadidi@gmail.com
}

\begin{abstract}
Quercus semecarpifolia is a high altitude oak and dominant species of central Himalayan vegetation. In the central Himalaya, plants are subjected to a prolonged dry period, thus developing moisture stress. Soil water potential at $15 \mathrm{~cm}$ and $30 \mathrm{~cm}$ depth, predawn and midday leaf water potential and their relationship with stomatal conductance and phenological behaviour was studied at Phulchowki Hill, Kathmandu to evaluate the drought adaptation strategy of $Q$. semecarpifolia in a pure stand at $2130 \mathrm{~m}$ elevation. The natural ecosystem of Himalayan region has a characteristic climatic pattern of concentrated rainfall and a prolonged dry season which have a strong effect on the adaptability of this species. It maintained a high predawn leaf water potential $\left(\Psi_{\mathrm{L} p d}\right)$ and stomatal conductance $\left(\mathrm{g}_{\mathrm{w}}\right)$ despite low soil water $\Psi$ and $\Psi_{\mathrm{L} p d}$. Lowest $\Psi_{\mathrm{s}}$ and $\Psi_{\mathrm{L} \text { pd }}$ were observed in March 1999, when there was almost no rain for five months. Mean $\Psi_{\mathrm{L} p d}$ and $\Psi_{\mathrm{L} \text { md }}$ were (-1.79 and $-2.29 \mathrm{MPa}$, respectively). Patterns of $\Psi_{\mathrm{L} \text { pd }}$ and $\Psi_{\mathrm{L} \text { md }}$ correlated significantly with soil $\Psi$, and phenology as $\Psi_{\mathrm{L} \text { pd }}$ often increased during leafing but not with $\mathrm{g}_{\mathrm{w}}$.
\end{abstract}

Key words: Drought adaptation, oak, Phulchowki hill, Quercus semecarpifolia, stomatal conductance and water potential.

\section{INTRODUCTION}

Quercus semecarpifolia, a high altitude oak, is an evergreen dominant species of central Himalayan vegetation, and is distributed from southwest China to Afghanistan, at elevations of 2100 to $3800 \mathrm{~m}$ asl. It occurs in moist temperate and sub-alpine regions with heavy snowfall and moderate rainfall, and is absent from the dry regions of the inner Himalayas (Negi and Naithani 1995). Q. semecarpifolia is also considered as one of the oldest vegetation of Himalayan zone which invaded the prairieland of the Himalayas and became the dominant species of then sub-alpine and alpine forest (Singh and Singh 1992). In fact, oaks occupy a very prominent place in the ecosystem of not only the Himalayan region but according to Gailing et al. (2009) Quercus spp. are a model for forest tree species, being one of the most important forest genera in northern hemisphere.

The natural vegetation of central Himalayas reflects a strong and extensive environmental gradient. The climate is characterized by concentrated rainfall from mid-June to midSeptember. Such warm season rainfall and complimentary eight to nine months of drought are likely to have profound effects on adaptation and ecosystem processes (Singh and Singh 1992, Zobel 
and Singh 1997). The structural and physiological adaptations to drought determine the growth and survival of forest tree species in dry climates (Tenhunen et al. 1987). Role of the environment, particularly drought in controlling the distribution and performance of species is poorly understood in Himalayan region. As plant growth is chiefly associated with the maintenance of a favourable water status, such prolonged dry period may be a limiting factor for the growth and development of this species.

Phulhowki Hill has typical warm temperate monsoon climate with three seasons round the year: cold and dry winter (October to February), pre monsoon dry summer (March to May) and monsoon (June to September). There is no perennial source of water above $1600 \mathrm{~m}$ in Phulchowki Hill.

Water moves from the soil through the plants to the atmosphere along a gradient of water potential $(\Psi)$, the lowest $\Psi$ in the plants being at the leaf surface (Lambers et al. 1998). Tree $\Psi$ and its components play an important role in the physiology and metabolism of the plants (Kramer and Boyer 1995). The predawn water potential is considered as a good indicator of soil water availability and is an important reflection of plant water status. Predawn water potential varies along the environmental gradients indicating how plants integrate soil water availability; hence it is an useful measure of plant water status (Hinckley et al. 1983, Waring and Schlesinger 1985) and may correlate with maximum stomatal conductance (Reich and Hinckley 1989). Predawn $\Psi$ also reflects the water extraction capacity by root systems of trees (Aranda et al. 2000) and one of the most important expressions of the water relations in higher plants is the maintenance of an efficient water conducting system based on its hydraulic conductance. Also the changes in tissue elasticity in response to drought modify the relationship between turgor pressure and cell volume that may contribute to drought tolerance (Zlatev and Lidon 2012). Hence turgor maintenance is of critical importance because the turgor necessary for leaf expansion must develop in these trees despite low water availability (Kramer and Boyer 1995). Osmotic adjustment which increases the osmotic force thus promoting water absorption is recognized as an effective component of drought resistance (Martinez et al. 2007) and it provides a mean of maintaining cell wall water status.

In recent years, many research suggest that forests in certain areas might become more vulnerable to drought in the future not only due to water depletion but because of the amplified effect of changes in climate variability and extremes resulting from global warming. In the last decade, forest species composition change due to drastic drought spell in different forest ecosystems have been reported worldwide (Breshears et al. 2005, 2009). Similarly some cases of altitudinal displacement of drought sensitive forest trees, from lower and drier altitude to higher and wetter one have also been reported (Penuelas et al. 2008, Lindner et al. 2010). Thus it is a challenge to comprehend the basic interactions of plants and their environment to predict responses for now and in future in milieu of expanding demands of growing population, global warming and climate change in both managed and natural ecosystem (Waring et al. 2011).

Hence this study was focussed with the main objectives to find out: the relative importance of plant water potential for drought resistance and completion of phenological activities during the dry periods.

\section{MATERIALS AND METHODS}

The study was carried out at Phulchowki Hill $\left(27^{\circ} 33^{\prime} \mathrm{N}, \quad 8^{\circ} 22^{\prime} \mathrm{E}\right), \quad 10 \mathrm{~km}$ southeast of Kathmandu, Nepal. Quercus semecarpifolia was studied here at its lower elevational limit at $2130 \mathrm{~m}$ and forms a pure stand above $2400 \mathrm{~m}$. 
Soil water potential and leaf water potential were measured with a thermocouple psychrometer (Tru-Psi, Decagon, Pullman WA). Soil was measured at two depth 15 and $30 \mathrm{~cm}$ and leaf water potential was measured in leaves from three representatives at predawn (0500-0600 h) and midday (1300-1400 h).

Measurements were taken at a monthly interval for 24 times from December 1998 to January 2001.One monsoon month's observation was made in September 1999.

\section{RESULTS}

Soil water potential: Soil $\Psi$ at both depth $\left(\Psi_{15}\right.$ and $\Psi_{30}$ ) were mostly less than -1.0 MPa except in March, April, May and June 1999. As a result of 5 months of absolute dryness $\Psi_{15}$ was $<-1.5 \mathrm{MPa}$ from March (often called the Permanent Wilting Point) and in the following months till June 1999 (Fig. 1). Despite $6.0 \mathrm{~mm}$ rainfall on April 9, 1999, $\Psi_{15}$ couldn't recover on April 10 when measurement was taken. In contrast, the 2000 received more precipitation and $\Psi_{15}$ was from -0.2 to $-0.5 \mathrm{MPa}$. Mean $\Psi_{15}$ and $\Psi_{30}$ was $-0.46 \mathrm{MPa}$ and -0.44 MPa, respectively. There was significant difference in $1^{\text {st }}$ and $2^{\text {nd }}$ year of $\Psi_{15}$ and $\Psi_{30}$ (statistical source - Poudyal et al. 2003, 2004).

Leaf water potential: There was significant variation in $\Psi_{\mathrm{L} p d}$ months and years $(\mathrm{P}=0.001)$. The minimum values of $\Psi_{\mathrm{L} \text { pd }}$ and $\Psi_{\mathrm{L} \text { md }}$ were observed in March 1999 (Fig. 1) and maximum $\Psi_{\mathrm{L} \mathrm{pd}}$ and $\Psi_{\mathrm{L}}$ md were observed in June 2000 when monsoon starts. Predawn and midday leaf water potential showed a profound effect of precipitation on it and low value was observed during the dry summer month and mostly during the $1^{\text {st }}$ year of drought. $\Psi_{\mathrm{L} \text { pd }}$ reached a minimum value of $-4.747 \mathrm{MPa}$ (March1999) and recovered upto -0.763 MPa (June 2000) (Fig. 1). There was a significant difference in $1^{\text {st }}$ and $2^{\text {nd }}$ year of $\Psi_{\mathrm{L} \mathrm{pd}}$ and $\Psi_{\mathrm{L} \text { md }}$ $(\mathrm{P}=0.001)$.

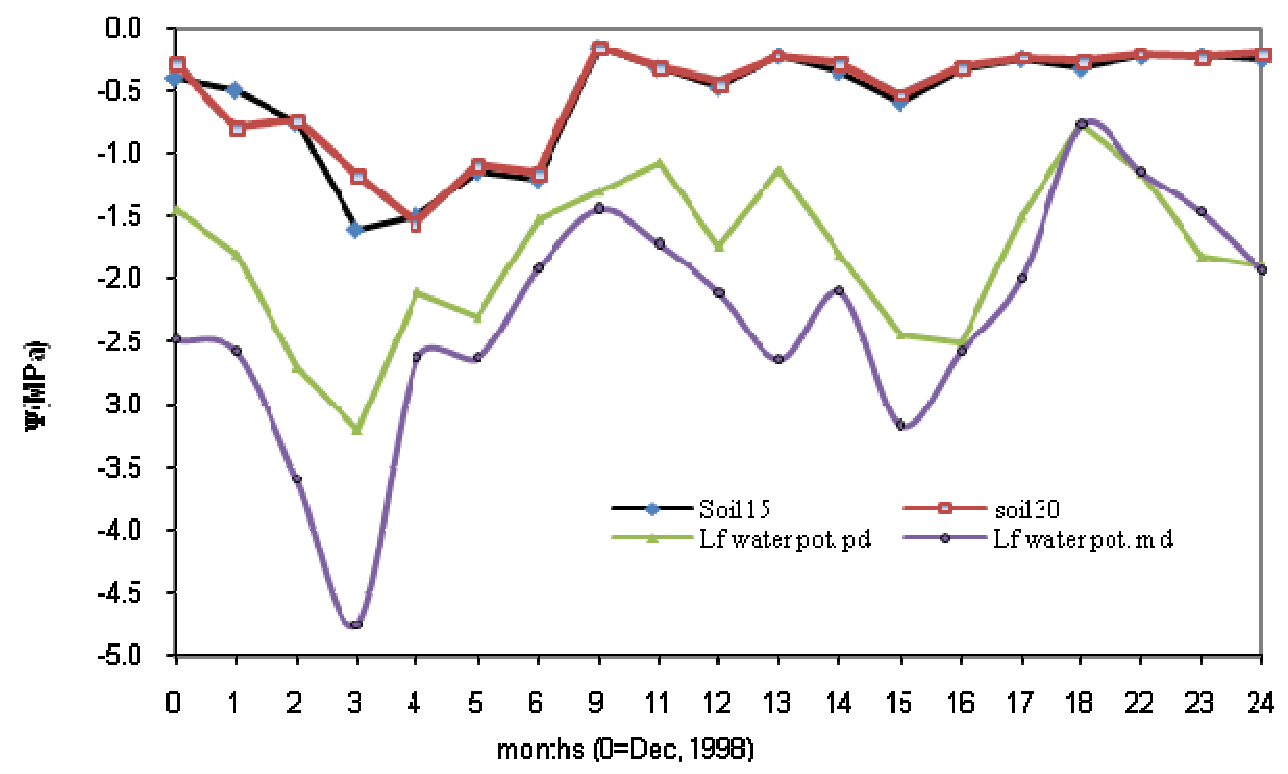

Fig. 1. Mean soil $\Psi_{15}, \Psi_{30}$, Leaf water potential at predawn and midday in $Q$. semecarpifolia. 


\section{DISCUSSION}

Seasonal variation of leaf water potential $\left(\Psi_{\mathrm{L}}\right.$ pd and $\Psi_{\mathrm{Lmd}}$ ) illustrated the pattern of precipitation as the lowest value was found in March 1999, the driest period when there had been only $5.4 \mathrm{~mm}$ rainfall at the end of five months. Similar result was shown by soil $\Psi$ at both depths. Similar observation was made by Zobel et al. (2001) in oaks in the Central Indian Himalaya during the dry season of 1995 , when soil $\Psi$ reached a minimum of $-3.51 \mathrm{MPa}$, in contrast to the average $<-1.8$ MPa. Poudyal et al (2004) reported that $\Psi_{15}$ and tree $\Psi_{\mathrm{pd}}$ reached minimum values of - 4.9 $\mathrm{MPa}$ and -1.6 MPa respectively in C. indica in March 1999 growing at a lower elevation of $1400 \mathrm{~m}$. Drought was also stern during the pre-monsoon dry season of 1999 in Kumaun, in the central Indian Himalaya, west of Nepal where $\Psi_{\mathrm{pd}}$ reached -5.5 MPa in Q. floribunda (Singh et al. 2000).

$\Psi_{30}$ was higher than $\Psi_{15}$ and correlated significantly with $\Psi_{15}$ and specified the same seasonal patterns of variation.

Predawn $\Psi$ has been considered a good indicator of $\Psi_{\mathrm{s}}$ (Kramer and Boyer 1995, Paulilo et al. 1998) because equilibrium may be established in the soil-plant-atmosphere continuum before dawn. $\Psi_{\mathrm{L} \mathrm{pd}}$ and $\Psi_{\mathrm{L} \text { md }}$ were lower than soil $\Psi$ at both depths, mostly in winter, when low temperature might decrease water movement from the soil into the roots, reducing leaf $\Psi$. As the pathway of water from the soil to the atmosphere takes place along a gradient of water potential $(\Psi)$, the lowest $\Psi$ in the plants is at the leaf surface (Lambers et al. 1998). Due to the evaporative demand during dry seasons, $\Psi$ among the plant gradient becomes more pronounced as tree water $\Psi$ was - 1.6 and $-2.4 \mathrm{MPa}$ in morning and afternoon (Poudyal et al. 2004) in comparison to 3.2 and $-4.75 \mathrm{MPa}\left(\Psi_{\mathrm{Lpd}}\right.$ and $\Psi_{\mathrm{L} \mathrm{md}}$ respectively) in March 1999. After the monsoon (July to September), cold and dry winter (October to February) prevails and temperature difference between predawn and afternoon increases by and large and hence due to the evaporative demand leaf $\Psi$ decreased even though soil $\Psi$ and tree $\Psi$ was comparatively high (Fig. 1).
Similarly, the effect of dryness is more effectual in leaf than in soil as both $\Psi_{\mathrm{L} \text { pd }}$ and $\Psi_{\mathrm{L} \text { md }}$ showed decreasing tendency from February 1999 onwards and reached minimum in March 1999 as in soil $\Psi$, but in April 1999, soil $\Psi$ replenished due to the previous day $6.00 \mathrm{~mm}$ rain, which was not found in $\Psi_{\mathrm{L} \text { pd }}$ and $\Psi_{\mathrm{L} \text { md. Similarly, the diurnal }}$ change in predawn and midday leaf $\Psi$ was minimum in June, October and November 2000, which could be attributed different climatic effects as temperature, light and relative humidity. In June 2000 , the predawn temperature was $19.2^{\circ} \mathrm{C}$ with $\mathrm{RH} 79.7 \%$ while the midday temperature was $22.1^{\circ} \mathrm{C}$ and $\mathrm{RH}$ decreased to $66.8 \%$. Also the stomatal conductance was higher in morning than in the afternoon during these months (Poudyal et al. 2004) which can be responsible for minimum diurnal change. Poudyal et al. (2004) reported higher value of predawn and midday tree $\Psi$ in $Q$. semecarpifolia during the same period.

A diurnal change $\left(\Psi_{\mathrm{md}}-\Psi_{\mathrm{pd}}\right)$, which is the ability of plants to recover water $\Psi$ diurnally that is lost through leaf conductance, reflected seasonal variation as it increased during dry months. Further low illumination on hazy days played its role in decreasing diurnal change mostly in winter months. Mean diurnal change in leaf $\Psi$ was $-0.50 \mathrm{MPa}$ which was comparatively lower than tree water $\Psi$ (-0.77 MPa), (Poudyal et al. 2004). Rain water is available to the roots of the plants for a certain period then it either percolates down or evaporates from the surface, which lowers the soil $\Psi$ after precipitation is over. However, occasional replenishment of $\Psi_{\mathrm{s}}$ was done by pre-monsoon and winter precipitation in the $2^{\text {nd }}$ year of observation due to sporadic pre monsoon and winter precipitation.

$\Psi_{\mathrm{Lpd}}$ ranged from - 0.78 MPa to - 3.2 MPa and $\Psi_{\mathrm{m} \text { pd }}$ from -0.78 MPa to -4.75 MPa. Poudyal et al. (2004) reported a range of $\Psi_{\mathrm{pd}}$ : $-0.1 \mathrm{MPa}$ to -1.7 $\mathrm{MPa}$ during the same period. A similar range of tree $\Psi_{\text {pd }}$, i.e. $-0.2 \mathrm{MPa}$ to $-1.6 \mathrm{MPa}$ in $Q$. leucotrichophora by Tewari (2000) and from - 0.4 MPa to - 1.1 MPa in Q. leucotrichophora and $Q$. floribunda Lindl. (Zobel et al. 2001) In March 
1999, when $\Psi_{15}$ and $\Psi_{\mathrm{L} \text { pd }}$ reached minimum values, other Himalayan tree species viz; $Q$. lanata, Rhododendron arboreum, $C$. indica and Schima wallichii showed similar results (Poudyal et al. 2004).

Relationship with stomatal conductance and phenology: There was occasional rise in $\Psi_{\mathrm{L} \mathrm{pd}}$ in the studied species during the dry season which could be related to the phenological development of the species beside intermittent pre monsoon rain and reduced stomatal conductance. An alternative explanation for the rise in leaf $\Psi_{\mathrm{pd}}$ in May and June 2000 and January 2001 is the thin canopy, caused by lopping of the trees by villagers who collected fodder for farm animals from the forest thus decreasing conducting surface.

Q. semecarpifolia, which has the longest leaf emergence and expansion period (March to mid September) raised $\Psi_{\text {Lpd }}$ during the period of maximum leaf expansion. Such increase in $\Psi_{\mathrm{Lpd}}$ agrees with Reich and Borchert's (1984) hypothesis, which states that phenomorphology varies as a consequence of differences in water availability and changes in internal water status.

Stomatal responses to water availability in soil, leaf and atmosphere are highly interactive. Hinckley et al. (1983) found a decrease in stomatal conductance during dry periods as a reciprocal function of the predawn leaf water potential in oaks. Stomatal conductance decreased in dry months when tree water potential were at their lowest (Poudyal et al. 2004).

The conductivity of water from the leaf to air is probably the most sensitive and earliest indicator of the physiological status of the whole plant (Smith and Hollinger, 1991). Significant correlation $(P=0.02)$ was found for stomatal conductance $\left(g_{w}\right)$ with $\Psi_{\mathrm{L} \text { md }}$.

Q. semecarpifolia exhibited maintenance of high stomatal conductance over low predawn leaf water $\Psi$ i.e. $122.7 \mathrm{mmol} \mathrm{m}^{-2} \mathrm{~s}^{-1}$ at $-3.2 \mathrm{MPa}$ in March 1999. The range of $g_{w}$ AM was between 94 and $327 \mathrm{mmol} \mathrm{m}^{-2} \mathrm{~s}^{-1}$ (Poudyal et al. 2004). Despite low soil-water availability in dry months, this oak kept its stomata open and kept so till December when maximum $g_{w}$ was observed (Poudyal et al. 2004). Higher water use efficiency, which decreased the $\Psi_{\mathrm{L} \text { pd }}$ in December 1999, is reflected by a negative correlation between VPD and $g_{w}$. Such interdependency is reported by Aphalo and Jarvis (1991) in oaks and Gao et al. (2003) in coniferous pines.

Phenological development is related to tree water status during leaf expansion (Meinzer et al. 1983), Because some phenological activities are inhibited by moderate water stress (Borchert 1994a), phenological processes (leaf emergence, leaf expansion, flowering, and fruiting) took place primarily at the end of the dry season (Poudyal et al. 2012a), which indicates that this evergreen tree cannot rehydrate during a leafless dry season, as Borchert $(1994 a, b, c)$ describes for American dry tropical trees. But perhaps the low leaf $\Psi$ during the dry season was enough to allow tissue development, or the occasional rise in $\Psi_{\mathrm{L} \text { pd }}$ during the dry season in response to sporadic rainfall, reduced leaf area, or changes that increase water uptake was sufficient to allow phenological development.

In conclusion, $Q$. semecarpifolia, a high altitude inhabitant had low $\Psi_{\mathrm{L} \text { pd }}$, high $\mathrm{g}_{\mathrm{w}}$, low tissue elasticity and high osmotic potential. At higher altitude lower temperatures and more cloud prevails which, could support high $\mathrm{g}_{\mathrm{w}}$ even during soil drying. Further, low osmotic potential maintains a good osmotic adjustment thus compensating low tissue elasticity. $Q$. semecarpifolia showed high osmotic adjustment in response to low water availability, an ability to accumulate significantly high solute concentrations, where as an inelastic cell could be a potential advantage in maintaining cell/tissue integrity at lower soil and leaf $\Psi$ (Poudyal et al. $2012 b$ ). Further it increases the gradient between soil and water potential, thereby promoting more effective water uptake from drying soils as exhibited by high xylem conductivity (Poudyal et 
al. 2003). Thus, Q. semecarpifolia displayed different combinations of water relation parameters as low leaf and tree $\Psi$ over high $g_{w}$ to maximize photosynthesis in dry periods provided by an amicable environment of warm temperature, greater illumination and mature leaves with high stomatal conductance and a good osmotic adjustment, which seemed to be a drought tolerant strategy to survive in the drought prone Himalayas.

\section{ACKNOWLEDGEMENTS}

I would like to express my sincere thanks to Prof. Dr. P. K. Jha, Head, CDB, Tribhuvan University, Prof. Dr. D. B. Zobel, Oregon State University for their guidance. I would also like to acknowledge thanks to Dr. B. B. Shrestha, K. Mainali, N. Adhikari, K. Parajuli, K. Pokharel and R. Tripathee for their help during the field study and National Science Foundation for funding.

\section{REFERENCES}

Aphalo, P.J. and P.G. Jarvis. 1991. Do stomata respond to relative humidity? Plant, Cell and Environment 14:127-132.

Aranda, I., L. Gil and J.A. Pardos. 2000. Water relations and gas exchange in Fagus sylvatica L. and Quercus petraea (Mattuschka) Liebl. in a mixed stand at their southern limit of distribution in Europe. Trees 14:344-352.

Borchert, R. 1994a. Water status and development of tropical trees during seasonal drought. Trees 8:115-125.

Borchert, R. 1994b. Induction of rehydration and bud break by irrigation or rain in deciduous trees in tropical forests. Biotropica 24:385395.

Borchert, R. 1994c. Soil and stem water storage determine phenology and distribution of tropical dry forest trees. Ecology 75:14371449.

Breshears, D.D., N.S. Cobb, P.M. Rich, K.P. Price, C.D. Allen, R.G. Balice, W.H. Romme, J.H. Kastens, J.M.L. Floyd, J. Belnap, J.J. Anderson, O.B. Myers and C.W. Meyer. 2005. Regional vegetation die-off in response to global-change-type drought. Proceedings of the National Academy of Sciences. (ed.) H.A. Mooney. USA. 102:15144-15148.

Breshears, D.D., O.B. Myers, C.W. Meyers, F.J. Barnes, C.B. Zou, C. Allen, N.G. McDowell and W.T. Pockman. 2009. Tree die-off in response to global change-type drought: Mortality insights from a decade of plant water potential measurements. Frontiers in Ecology and Environment 7(4):185-189.

Gailing, O., B. Vornam, L.L. Leinemann and R. Finkeldey. 2009. Genetic and genomic approaches to assess adaptive genetic variation in plants: forest trees as a model. Physiologia Plantarum 137:509-519.

Gao, Q., S. Peng, P. Zhao, X. Zeng, M. Yu, W. Shen and Y. Liu. 2003. Explanation of vegetation succession in subtropical southern China based on ecophysiological characteristics of plant species. Tree Physiology 23:641-648.

Hinckley, T.M., F. Duhme, A.R. Hinckley and H. Ritcher. 1983. Drought relations of shrub species: assessment of the mechanisms of drought resistance. Oecologia 59:344-350.

Kramer, P.J. and J.S. Boyer. 1995. Water Relations of Plants and Soils. Academic Press, San Diego, USA.

Lambers, H., F.S. Chapin III and T.L. Pons. 1998. Plant Physiological Ecology. Springer Verlag, New York, USA.

Lindner, M., M. Maroschek, S. Netherer, A. Kremer, A. Barati, J. Garcia-Gonzao, R. Seidi, S. Deizon, P. Corona, M. Kolstrom, M.J. Lexer and M. Marchetti. 2010. Climate change impacts, adaptive capacity, and vulnerability of European forest ecosystems. Forest Ecology Management 259:698-709.

Martiınez, J.P., H. Silva, J.F. Ledent and M. Pinto. 2007. Effect of drought stress on the osmotic adjustment, cell wall elasticity and cell volume of six cultivars of common beans (Phaseolus vulgaris L.). European Journal of Agronomy 26:30-38. 
Meinzer, F., V. Seymour and G. Goldstein. 1983. Water balance in developing leaves of four savanna woody species. Oecologia 60:237243.

Negi, S.S. and H.B. Naithani. 1995. Oaks of India, Nepal and Bhutan. Dehradun, International Book Distributors.

Paulilo, M.T.S., G.M. Felippe and J.E. Dale. 1998. Root/shoot partitioning and water relations in Qualea grandiflora (Vochysiaceae) seedlings under water stress. Revista Biol. Trop. 46:4144.

Peñuelas, J., J. Sardans, R. Ogaya and M. Estiarte. 2008. Nutrient stoichiometric relations and biogeochemical niche in coexisting plant species: effect of simulated climate change. Polish Journal of Ecology 56(4):613-622.

Poudyal, K., P.K. Jha and D.B. Zobel. 2003. Seasonal changes in hydraulic conductance of Himalayan trees in response to drought. Ecoprint 10:59-73.

Poudyal, K., P.K. Jha and D.B. Zobel. 2012a. Role of wood water properties and leaf dynamics in phenology and response to drought in evergreen Himalayan trees. Ecoprint 19:7184.

Poudyal, K., P.K. Jha and D.B. Zobel. $2012 b$. Pressure - volume curve analysis in five Himalayan tree species. Physiological Ecology and Environmental Science 3(1\&2): 1-11.

Poudyal, K., P.K. Jha, D.B. Zobel and C.B. Thapa. 2004. Patterns of leaf conductance and water potential of five Himalayan tree species. Tree Physiology 24:689-699.

Reich, P.B. and R. Borchert. 1984. Water stress and tree phenology in a tropical dry forest in the lowland of Costa Rica. Journal of Ecology 72:61-74.

Reich, P.B. and T.M. Hinckley. 1989. Influence of predawn water potential and soil to leaf hydraulic conductance on maximum daily leaf diffusive conductance in two oak species. Functional Ecology 3:719-726.
Singh, J.S. and S.P. Singh. 1992. Forest of Himalaya: Structure, Functioning and Impact of Man. Gyanodaya Prakashan, Nainital, India.

Singh, S.P., A. Tewari, S.K. Singh and G.C. Pathak. 2000. Significance of phenologically asynchronous populations of the central Himalayan oaks in drought adaptation. Current Science 79:353-357.

Smith, W.K. and D.Y. Hollinger. 1991. Measuring stomatal behaviour. In: Techniques and Approaches in Forest Tree Ecophysiology. (eds.) J.P. Lassoie and T.M. Hinckley. CRC Press, Boca Raton, Florida, USA. pp. 141-174.

Tenhunen, J.P., O.L. Lange and R.W. Pearcy. 1987. Diurnal variations in leaf conductance and gas exchange in natural environments. In: Stomatal Function. (eds.) E. Zeiger, G.D. Farquar and I.R. Cowan. Stanford University Press, USA. pp. 323-351.

Tewari, A. 2000. Water status measurements in a banj oak (Quercus leucotrichophora A. Camus.) forest in Kumaun Central Himalayas. Journal of Environmental Biology 21(1):2327.

Waring, R.H. and W.H. Schlesinger. 1985. Forest Ecosystem - Concept and Management. Academic Press, Orlando, USA.

Waring, R.H., J. Chen and H. Gao. 2011. Plant water relations at multiple scales: integration from observations, modeling and remote sensing. Journal of Plant Ecology 4(2):1-2.

Zobel, D.B. and S.P. Singh. 1997. Himalayan forest and ecological generalizations. Bioscience 47:735-745.

Zobel, D.B., S.C. Garkoti, S.P. Singh, A. Tewari and et al. 2001. Patterns of water potential among forest types of the central Himalaya. Current Science 80:774-779.

Zlatev, Z. and F.C. Lidon. 2012. An overview on drought induced changes in plant growth, water relations and photosynthesis. Emir. Journal of Food and Agric. 24(1):57-72. 